\title{
An economic system that crushes the poor
}

\begin{tabular}{|c|c|}
\hline \multicolumn{2}{|c|}{$\begin{array}{l}\text { Author: } \\
\text { Maake J. Masango }^{1}\end{array}$} \\
\hline $\begin{array}{l}\text { Affiliation: } \\
{ }^{1} \text { Department } \\
\text { Theology, Facu } \\
\text { Theology, Uni } \\
\text { Pretoria, Soutl }\end{array}$ & $\begin{array}{l}\text { f Practical } \\
\text { Ity of } \\
\text { ersity of } \\
\text { Africa }\end{array}$ \\
\hline $\begin{array}{l}\text { Note: } \\
\text { This article wa } \\
\text { presentation t } \\
\text { Symposium } 20 \\
\text { by Prof. Dr Joh } \\
\text { Meylahn, Dep } \\
\text { Practical Theo } \\
\text { of Theology, U } \\
\text { Pretoria, Preto } \\
\text { South Africa. }\end{array}$ & $\begin{array}{l}\text { s initially a } \\
\text { o the Poverty } \\
13 \text {, directed } \\
\text { ann-Albrecht } \\
\text { artment of } \\
\text { logy, Faculty } \\
\text { niversity of } \\
\text { ria, }\end{array}$ \\
\hline $\begin{array}{l}\text { Corresponden } \\
\text { Maake Masan }\end{array}$ & $\begin{array}{l}\text { ce to: } \\
\text { go }\end{array}$ \\
\hline $\begin{array}{l}\text { Email: } \\
\text { maake.masan }\end{array}$ & so@up.ac.za \\
\hline $\begin{array}{l}\text { Postal address } \\
\text { Private Bag X2 } \\
\text { 0028, Pretoria }\end{array}$ & $\begin{array}{l}\text { 0, Hatfield } \\
\text { South Africa }\end{array}$ \\
\hline $\begin{array}{l}\text { Dates: } \\
\text { Received: } 20 \mathrm{~N} \\
\text { Accepted: } 16 \mathrm{~J} \\
\text { Published: } 20\end{array}$ & $\begin{array}{l}\text { May } 2014 \\
\text { uly } 2014 \\
\text { Nov. } 2014\end{array}$ \\
\hline $\begin{array}{l}\text { How to cite th } \\
\text { Masango, M.J. } \\
\text { 'An economic } \\
\text { that crushes th } \\
\text { HTS Teologies } \\
\text { Theological St } \\
\text { Art. \#2737, } 5 \\
\text { http://dx.doi.c } \\
\text { hts.v70i1.2737 }\end{array}$ & $\begin{array}{l}\text { is article: } \\
\text {, 2014, } \\
\text { system } \\
\text { e poor', } \\
\text { Studies/ } \\
\text { udies } 70(1) \text {, } \\
\text { ages. } \\
\text { rg/10.4102/ }\end{array}$ \\
\hline $\begin{array}{l}\text { Copyright: } \\
\text { C 2014. The A } \\
\text { Licensee: AOS } \\
\text { OpenJournals. } \\
\text { is licensed unc } \\
\text { Creative Comn } \\
\text { Attribution Lic }\end{array}$ & $\begin{array}{l}\text { uthors. } \\
\text { S } \\
\text { This work } \\
\text { ler the } \\
\text { nons } \\
\text { ense. }\end{array}$ \\
\hline Read online: & $\begin{array}{l}\text { Scan this QR } \\
\text { code with your } \\
\text { smart phone or } \\
\text { mobile device } \\
\text { to read online. }\end{array}$ \\
\hline
\end{tabular}

The article focuses on economic structures that crush the poor, especially global economic structures that trap and keep people in poverty. The concept of poverty occupies centre stage in South Africa and many other developing countries. There is no longer a middle class. One is either rich or poor. Globalisation has created a system or program that continues to crush the poor, while also breeding greed and selfishness. The rich always accumulate resources while the poor struggle to make ends meet. These problems are created by the World Bank, the International Monetary Fund, and Structural Adjustment Programs, to name a few. These structures have introduced a system of inequality that widens the gap between the rich and the poor because of self-interest, which continues to crush the latter. The end result is that the concept of Ubuntu or Botho among African communities is destroyed. Injustice becomes the order of the day.

\section{Introduction}

In dealing with the topic of an economic system that crushes the poor, I recall two stories of poverty from my youth. As I grew up, my mother always cared for the poor and sent us to give them food. Whenever she cooked, she would make an extra portion to give to our neighbours. The Masikanas were struggling to make ends meet. They also came to our home to ask for sugar and tea. As children we would ask mother why. She always responded as follows: 'When you grow up you will understand the reason why they are asking for food.' The idea of sharing was part of our upbringing. This story of poverty reminds me of a statement in the Gospel of Mark that troubled me when I started ministry in a rural poor community: 'The poor you will always have with you and you can help them anytime you want' (Mk 14:7).

The second example relates to us children requesting our dad to buy us peanut butter. He kept on promising but failed to deliver. One day, my younger brother (the secondborn, known as The Terrible Two) confronted him. Dad's reply was that it would be bought at 'Mafelo a kgwedi' (which means at the end of the month). The problem is that we did not know when this time would come. We kept asking mother to let us know when 'Mafelo a kgwedi' came. The idea was to remind dad to buy peanut butter. Mathunya (the secondborn brother) again confronted him. At the end of the month dad brought his pay in a brown envelope and we were called to come to the table. He gave mother the envelope and asked her to take out all the money. He then asked her to take the money for the church, which she did. Then the money for rent, transport, food, school fees, et cetera, followed. Just a few pennies were left. He then said to us: 'This is how life is. The only thing I ask of you is to get your education, and then you will never have to face what we are facing right now. Then you will never be poor.' He added: 'Once you are educated, no one in this system of oppression can take that away from you. ${ }^{1}$

As I write this article, I realise to what extent my parents deprived themselves of certain basic necessities in order for us to eventually break the cycle of chronic poverty. Adair (2002:451) justly said that 'poverty is fundamentally an issue of exclusion and the absence of what others do not have within society as de facto or normative rights and entitlement.' Oduro and Aryee (2003:103) give an apt and interesting description of poverty when they say: 'It ranges from poor health, malnutrition, shortage of cash and food to the inevitable illiteracy.'

The two examples I gave as introduction, and the quotations above will help us to enter into the space of poor people, and thus experience their pain caused by a lack of basic necessities in life. Being part of that poor community troubled me. It also caused me to seek pastoral ways of dealing with this issue. That was the beginning of my intervention in order to change the order or the system that continued to crush the poor. At the time, I had a real struggle with the issue of poverty.

1.This took place at home when we were young and did not comprehend what poverty was 


\section{Poverty and its causes}

With the above quotations in mind, it is important to note that poverty is the condition created by the failure of the economic system. Its results are sometimes hidden, because poverty can last for generations, and people adapt to it by being creative in order to survive. For those who are poor, the economic system does not provide adequate food, water, housing, clothing, and health care, resulting in trauma and a declining quality of life.

To address this issue, one needs to understand how the system creates poverty in developing countries. The concept of poverty occupies centre stage in our country, South Africa, since the dawn of democracy in 1994. Since then, we have seen people begging for food at traffic lights, in shops and even at our homes. The pain of having nothing seems to be more obvious in urban areas. Formerly, it could be seen in the homelands and black townships, because they were structurally designed to be poor. Those of us who travel abroad know that this is no longer a problem of the so-called developing countries only, but it is a global issue. The World Bank, which is the leading institution in the drive for global transformation of the lives and living conditions of people in poor countries, declared that it is committed to the 'dream' of a world free of poverty (World Development Report 2003). One could ask whether this is a realistic goal. Can we eradicate poverty in our lifetime? What about the biblical statement: '[T]he poor you will always have with you' (Mt 26:11)?

If this issue is to be tackled, all the stakeholders (i.e., state, market, private enterprise and other non-governmental organisations) need to engage with the poor. Such involvement will help create or design a national policy on poverty eradication. The United Nations has taken steps towards this, but it is doing so on behalf of the poor, not with the poor. In other words, they involve leaders and heads of state who may not have grassroot experience of what it means to be poor. Therefore, it remains to be seen whether what is claimed as the more inclusive basis of Poverty Reduction Strategies (PRS) has widened the terms of debate about what poverty is and how it should be addressed in countries that have adopted it (Green \& Hulme 2005). These key issues are also questioned by Craig and Porter (2003). PRS have affected many African, Latin American as well as Asian countries. This process, when forced upon poor people by Western nations, makes the former respond with violence. No wonder South Africa is experiencing violence in townships which are home to the majority of poor people. It is not surprising to see poor people responding with violence in order to be noticed. They are seeking ways to have their problems addressed by those who make decisions in the country, especially institutions that work with social grants. In such situations violence is often experienced on a daily basis, not only the violence stemming from limited resources, but also the violence that comes when people reach the limits of their ability to adjust psychologically to a particular situation. Some poor communities develop resilient attitudes and behaviours that enable them to survive economic difficulties. For others, the breakdown of individuals, the family and the local community actually contributes to interpersonal violence. Duchrow has reason to state: 'Money and power of decision makers changes the soul of people' (in Duchrow \& Hinkelammert 2012:11).

The reader will realise that poor people are caught between the powers of government and those of world economic forums, such as the World Bank and the International Monetary Fund (IMF). Unfortunately, the World Bank, together with the IMF, has actually aggravated the situation, especially in developing countries. The classic case is Zimbabwe. Several countries, politicians and activists have addressed poverty by analysing the economy, in particular how it excludes poor people. Despite recent innovations, a money matrix understanding of poverty as an income or consumption shortfall continues to dominate poverty reduction and development policy analysis (Kanbur \& Squire 2001:50).

Kanbur and Squine (2001) suggest that:

... this is driven by advances which are measured within a paradigm centered on economics, both as a theoretical framework for assessing development policies, and as the prime means of affecting development policies, and as the prime means of affecting development as economic growth. (p. 87)

In short, poverty reduction is perceived as the result of economic policies and the production strategies of individuals and households, with poverty as a predicament into which they fall and from which they can be lifted if their income increases. This process focuses on finance (economy) at the expense of human beings, and never addresses the causes of poverty.

One is aware (through reading of scholars, such as Mbiti, and Mugambi, as well as experiences in Africa) that capitalism has no respect for humanity, and that it oppresses the poor, leaving them to survive on the crumbs or leftovers that fall from the tables of the rich. The system produces inequality and widens the gap between rich and poor. Since the dawn of democracy in South Africa, the focus is on self-interest, which has now destroyed the concept of Ubuntu or Botho among African communities. It produces injustices among human beings. O'Connor (2001:47) articulates this process well and captures the destruction it brings in villages and communities by saying: 'When this system is allowed to operate unchecked, self-interest seems to increase the gulf between the rich and the poor,' thereby destroying Ubuntu.

The forces described above will eventually decrease competition and stifle free enterprise, further concentrating wealth in the hands of a few privileged individuals, the Bill Gates of the world. The role China is playing in Africa is a classic example. As a result of its involvement, small shops are closing down. This, in turn, creates poverty and destroys families by forcing people to migrate to greener pastures. The reader needs to note that in former times private property ownership was not part of African people's 
lives. The land belonged to the whole village and members of the community jointly took care of it. However, with this kind of development (i.e. removal of the small businesses) taking place, this process of alienation has become the norm. This issue deserves attention because it has caused division among families, villagers, and communities. Zimbabwe is a classic case. Lots of people have migrated to South Africa. O'Connor (2001) comments by saying:

As soon as the land of any country has become private property, the land of the lords, like all other men [sic] love to reap where they have never sowed, and demand a rent even for its natural produce. (p. 47)

In other words, people abandon their land and migrate to urban areas, looking for money. When allowed, this system crushes the indigenous people who finally become poor. Economic structures are protected against humanity. Injustices become the order of the day. Some accept it as an operative principle and natural right of land owners, while it may appear that on a superficial level others are correct in saying that it is also apparent that the unrestricted accumulation of private property can become oppressive and finally displace people from the land (cf. Arrighi 1994). A classic case is the Land Act of 1936. During the apartheid days, black people were displaced from the land of their ancestors. Duchrow defines this process as one that breaks solidarity among poor people. He says:

Solidarity among peasants broke down with the introduction of both private property and money (with interest) leading to the accumulation of land, on the one hand, and loss of land plus debt slavery, on the other hand. (Duchrow \& Hinkelammert 2012:15)

Besides direct oppression in South Africa, this process also introduced indirect, anonymous forms of extracting surplus production, which promoted the splitting of societies into rich and poor. One is not surprised by how capitalism embarked on a concerted drive towards temporary and part-time employment, which provides decent wages on an unpredictable basis only. The resulting insecurity makes family life very difficult. Care-givers and counsellors need to be particularly sensitive to the various kinds of economic vulnerability poor people face. Rosaldo (1993) was right when he said:

Economic vulnerability is defined as the limits of the resources and adaptability of the community [village] or an individual when faced with potential threats, which in other words means a community's [village's] ability to absorb the changes that are caused by disaster in a particular milieu. (p. 56)

The result of the above is that communities are divided into a class of oppressor (rich) and a class of the oppressed (poor) - owners and labourers. Because of present inequalities, the latter class will seek radical reform and redistribution of both property and capital, while a class of defensive and conservative landowners will seek the preservation of the status quo. One understands the reaction Marx showed towards capitalism. He articulates the concern by saying:

The concentration of property in private hands results in alienation of human beings from their 'species beings' and a retreat into individualism. (in Blunden 2000:56)
According to Marx, alienation occurs within the proletariat when workers do not have ownership and control of the means of production, and are thus forced to sell their labour and become poor and alienated from their work. Duchrow and Hinkelammert (2012:11) observe that '[i]n the market place, money owners have more power than the producer of the commodity'. In other words, money offers access to the market, while the product first has to be in demand. Coping with this risk is only possible by having as much money as possible. This is the objective basis for the greedy to accumulate money without limit. Self-interest and profit making become the order of the day and workers get exploited thereby increasing their poverty. As a result, competition rather than cooperation, dominates the economic and social relations of persons. The key problem of the money-property economy is the splitting of society into winners and losers. In short, capitalism encourages tribalism that concentrates wealth with a few and withholds wealth from the poor. Heilbroner (1999) was right in saying that:

It is the right of all people to reap private benefits from use of the means of production and the right to utilize the dynamic forces of the market place for private enrichment ... very few wish to recognize that in reality, the operative results [lie] in favoring certain individuals and groups. (p. 71)

Many people believe that land, labour and capital are merely neutral factors in an impersonal and impartial market system. For the poor, the reality is the opposite; they paint a very different picture of modern capitalism. Heilbroner (1999) further points out that:

The operation of capitalism as functional system results in a structure of wealth and income characteristic of capitalism as a system of privilege - a structure in which the top two percent of all American families own between two thirds and three quarters of all corporate stock and where the top two percent of all receivers enjoy incomes roughly ten times larger than the average received within the nation as a whole. (p. 72)

This kind of set-up is catching up with us in South Africa (Nkandla and certain black people climbing the economic ladder being typical examples). When people enter into leadership roles, which have perks and benefits, and as they accumulate wealth, their riches do not respect the colour of the person. For example, during apartheid it was whites who oppressed the poor blacks, while in the new dispensation a black minority is now oppressing the black majority as well as the whites. Ultimately, such systems of privilege lead to nepotism and create a hierarchy of rigid socio-economic distribution that paralyses the initiatives of the poor, leading to defensiveness, suspicion and capriciousness of the rich. Who suffers in the end? It is the poor. Mbiti (2012:119) was right when he said: 'When two elephants fight, the grass gets hurt.'

The grass represents the poor. The above proverb will help us to analyse and understand how an economic structure crushes the poor, especially when it is implemented by the rich who have introduced systems of globalisation which continue to cripple the poor. In order to analyse this system we need to understand economic systems in general. 


\section{Economic systems}

The term economy can be traced back to Greek culture the Greek term is 'oikonomos', meaning one who manages a household. It derives from 'oikos', house, and 'nomos', rule. Further, it should be noted that 'oikonomos' is derived from 'oikonomia' which has not only the sense of management of a household or family, but also includes a sense such as thrift, direction, administration, arrangement and public revenue of a state. The word 'economy' first appeared in 1440. It is explained as the management of economic affairs (Johnson 2008:583). One needs to understand the origin of the term to be able to analyse and solve the problem of poverty.

With the above in mind, let us now assess how the poor are crushed by the economic structures of globalisation.

As mentioned earlier, it is unfortunate that the poor are always assessed or measured within the paradigm centred on economics, both as a theoretical framework for assessing development policies and as the prime means of effecting development in terms of economic growth (Kanbur \& Squire 2001:87). In other words, they are viewed as a commodity and have to produce for the owners.

When dealing with the United Nation's Millennium Development Goals, which are planned and implemented for the poor, note that those are being undertaken not with the poor but for the poor. I understand the reason why the process crushes them. The goals are powerful but have to be implemented by the very same people who create structures that crush the poor. Poverty reduction to them is perceived as the result of economic policies and the productive policies of individual households, with poverty as a state into which people fall and from which they can be lifted if their income increases (poor people are now treated as objects), while participatory poverty assessments have been billed as a means by which the economists' understanding of poverty can be extended and deepened (Kanbur \& Squire 2001:68).

A good argument is found in the explanation of Kanbur and Squire (2001:68-69). They suggest that this process fails to share a deeper understanding of poverty. It limits itself within economic structures and fails to move beyond their characteristics towards a deeper understanding of real poverty. The developed countries will thus see poverty as represented in development. In short, the process does not take seriously the status of humanity and its dignity, but works towards attacking the poor at the expense of the social relations that generate it. Therefore, it serves to construct the kinds of policy responses to it that development can manage, both conceptually and as the target of development interventions (Green 2005:47). This process contributes to the misrepresentation of poverty and to its perpetuation as an effect.

\section{Approach}

As we work with the issue of the poor, we should not avoid working 'with them in such a way that they share their own story' (Wimberly 2003:34). The film 'Joe Slovo' seeks a way in which poor people share their own stories. In the film I noticed that the males did the talking, while women were left out of the discussions. Nevertheless, they shared the depth of poverty experienced by that community. We cannot participate in methods of liberating the poor without engaging them in development dialogues. This point was made clear by those men who shared their story in the film. They emphasised the need for people to work together in order to address the issue of poverty. Honneth's psychological concept which emphasises the way we should work with each other, comes to mind where he says: 'The self emerges in relation to others' (Honneth 1996:87). The self cannot develop without the help of the other person. Therefore, if we leave the poor people out, we will act in the way that scholars have done. They have highlighted the participating causes of poverty at individual and household levels while underplaying the social relations and categorisation which can contribute to long-term poverty. The concept of the whole village raising a child is extremely important. What is the way forward?

\section{Affirming the poor}

When dealing with the issue of poverty and poor people, we have to bear in mind that poor people are human beings, and therefore, we need to return to the basic concept of Ubuntu. Ubuntu understands the need for an improved quality of life among human beings. LenkaBula further develops the concept of Ubuntu or Botho, one of the viable principles for justice which forces us to affirm those who are crushed by the economic structures of globalisation. She emphasises the essence of humanity, which is lived within the village or community. In this regard, LenkaBula (2010) says:

The essential elements associated with 'botho' are solidarity, cosmic relationality and awareness of humanity's intimate connectedness with creation, that we are fully human because we are and because we are inextricably bound to life and creation. (p. 113)

In short, one cannot afford to live life alone; we belong to each other. Mbiti (1979:56) further expanded this concept by saying: '... we are because you are, and you are because we are.' This statement emphasises the essence of being human together. Mnyaka (2003:31) refers to this concept as a set of ideals that guide and direct the patterns of life. As such, it implies neighbourly behaviour which also requires solving the gap between rich and poor. We need to open a new way of relating to each other.

Honneth (1996:70) reminds us that 'bringing people together in resistance and struggles for alternatives has, at the same time, therapeutic effects.' Harnessing this way of life will make us respect each other as fellow human beings. Ubuntu places us in this kind of relationship that requires or expects us to treat each other with goodness and dignity - a duty expected from us as we relate to each other.

Mokgoro (1998:3) further developed this concept as a basis for an ethics of cooperation, compassion, communalism and 
concern for the interests of collective respect for the dignity of personhood, while at the same time emphasising the virtue of that dignity in socio-economic relationships and practices.

Poling (2012), on the other hand, says, '[t]he village life is a system that organizes human desires, deciding what value and behaviors will shape the personal experiences of groups' (p. 11).

This kind of community is one that avoids competition and is one in which people help each other so that human beings are cared for. This way of living I have experienced in rural areas in South Africa, and in some parts of Zambia. Togetherness makes us to be sensitive to each other.

This idea can be enhanced by addressing the injustices that prevail in our communities. One way of dealing with poverty is to address the injustices that occur in our communities, and the rest of the global village. That is why Ubuntu is not in favour of a monopoly of control and hoarding of lifesustaining resources by the rich few. This concept opens a space where dialogue and participation (by both poor and rich) becomes the order of the day. Ultimately, it has to lead to and encourage the use and sharing of resources for the uplifting of all people in a village. When poverty is addressed from the viewpoint of justice, it will restore human dignity. LenkaBula (2010:114) completes this thought by saying: 'Botho/Ubuntu considers people not only as means to ends but also as ends in themselves, hence the requirement that relationships ought not to be based on exploitation and abuse.'

While justice provides one way of tackling the issue of poverty, Ubuntu offers the vehicle by which to bring about justice. Ubuntu requires us to relate to each other as human beings and it restores the concept of respect that is embodied in village life. In this way, we will no longer allow poor people to be crushed by economic structures which continue to support the rich at the expense of the poor.

\section{Conclusion}

My hope is that pastoral care and counselling will be as actively engaged in informing itself about the structural situation that creates suffering as the global relief and humanitarian agencies have been doing, and that we (villagers) will share responsibility for the rearrangements that have positive ramifications for the poor in developing countries.

Finally, together we will reinstall trustworthy villages which will respect human life in contrast to structures such as the IMF and the World Bank that destroy human dignity. Let me conclude by sharing Switzer's (2000) words of wisdom:
Persons who live in the midst of economic vulnerability need trustworthy communities [villages] because they need places where they can be relieved from the pressure of survival, and can gather their resources for fighting another day. (p. 81)

Pastoral care should empower the rich and care-givers to enable them to work for justice on behalf of others. This way of living will help us to see God's image and likeness in each other. This is a gift given to all humanity. Therefore, all economies must be built on God's gift to improve the life of all human beings.

\section{Acknowledgements Competing interests}

The author declares that he has no financial or personal relationship(s) which may have inappropriately influenced him in writing this article.

\section{References}

Adair, V., 2002, 'Branded within the family: Inscription of poverty and class in the United States', Journal of Women in Culture and Society 27(2), 38-43. http://dx.doi.org/10.1086/495693

Arrighi, G., 1994, The long twentieth century: Money, power, and the origins of our times, Verso, London.

Blunden, A., 2000, 'Forword to Hegel's logic', in Marxists Internet Archive Publications, viewed 10 August 2013, from http://marxists.org/reference/archive/hegel/index.htm

Cooper, F. \& Packard, M. (eds.), 2004, International development and the social sciences, University of California Press, Berkeley, CA.

Craig, D. \& Porter, D., 2003, Poverty reduction strategy papers: A new convergence, Cambridge University Press, Cambridge.

Duchrow, U. \& Hinkelammert, F.J., 2012, Interreligious solidarity for just relations Transcending greedy money, Palgrave Macmillan, New York, NY.

Green, M., 2005, Representing poverty and attacking representations: Some anthropological perspectives on poverty in development, GPRG Publishers, Oxford. http://dx.doi.org/10.1016/j.worlddev.2004.09.013

Green, M. \& D. Hulme, 2005, 'From correlates and characteristics to causes: Thinking about poverty from a chronic poverty perspective', World Development 33(6), ab7-879.

Heilbroner, R.L., 1999, The world philosophers: The lives, times and ideas of the great economic thinkers, Simon and Schutse, New York, NY.

Honneth, A., 1996, The struggle for recognition: The moral grammar of social conflicts, MIT Press, Cambridge, MA.

Johnson, D.B., 2008, Dictionary of the English language, Merriam Webster, Cambridge.

Kanbur, R. \& Squire, L., 2001, The evolution of thinking about poverty: Exploring the interactions, Oxford University Press, New York, NY.

LenkaBula, P., 2010, 'Economic globalization, ecumenical theologies and ethics of justice in the twenty-first century', Missionalia 38(1), 99-120.

Mbiti, J.S., 1979, Introduction to African religion, 3rd edn., Praeger, New York, NY.

Mbiti, J.S., 2012, Concepts of God in Africa, 2nd edn., Acton Publishers, Nairobi.

Mnyaka, M.M.N., 2003, Xenophobia as a response to foreigners in post-apartheid South Africa and post-exilic Israel: A comparative critique in the light of the gospel and Ubuntu ethical principles, University of South Africa, Pretoria.

Mokgoro, J.Y., 1998, 'Ubuntu and the law in South Africa', paper presented at the colloquium on Constitution and Law, Potchefstroom University, Potchefstroom.

O'Connor, A., 2001, Poverty knowledge: Social science, social policy, and the poor in twentieth-century U.S. history, Princeton University Press, Princeton, NJ.

Oduro, A. \& Aryee, I., 2003, Investigating chronic poverty in West Africa, CPRC Press, Manchester.

Poling, J.N., 2002, Render unto God: Economic vulnerability, family violence, and pastoral theology, Chalice Press, St Louis, KY.

Rosaldo, R., 1993, Culture and truth: The remaking of social analysis, Beacon Press, Boston, MA.

Switzer, D.K., 2000, Pastoral care emergencies, Fortress Press, Minneapolis, MN (Creative pastoral care and counseling series).

Wimberly, E.P., 2003, Claiming God, reclaiming dignity: African American pastoral care, Abingdon press, Nashville, TN.

World Bank, 2003, World development report 2003, viewed 11 August 2013, from http://www.worldbank.org and http://www.dynamicsustainabledevelopment.org 